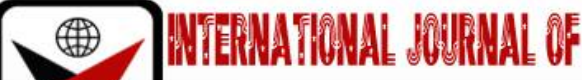

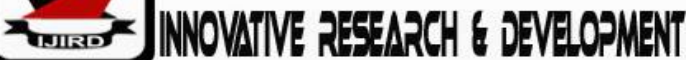

ISSN 2278 - 0211 (Online)

\section{Contemporary Art and the Ghanaian Experience: An Iconographic Assay}

\author{
Dr. Theophilus Kwesi Mensah \\ Lecturer, Department of Art Education, University of Education, Winneba, Ghana
}

\begin{abstract}
:
The primary focus of this study was to get a snug look at contemporary art and the Ghanaian experience with a critical look at the iconographies used by the Ghanaian contemporary artist. And extend perceptions of what philosophical underpinnings that inspires the Ghanaian contemporary artist in his quest to practice art. It was also intended that, the outcome of the study would be relevant for expanding the frontiers of knowledge in the field of art praxis in Ghana by helping to identify key factors that inform contemporary art in Ghana, which would help inform, deepen and enhance understanding of the essence of contemporary art in Ghana's spatial, temporal, spatio-temporal and three dimensional art landscape. The principal findings of this inquiry revealed that Ghanaian contemporary artists played a lot on their personal experiences to create artwork that explored idea son current social, political and economic issues, such as sustainable development, globalisation, migration or intercultural exchange, while others tackle more intimate questions of human relations, gender and sexuality, memory, life and death. From the analysis it came out clearly that the Ghanaian contemporary artists utilised a variety of media including photography, film, technology, fabric, metal, glass, found objects, scrap metals, waste materials, plastics, nature, paint, paper and the human body.
\end{abstract}

Keywords: Modernism, iconography, contemporary, found objects

\section{Background to the Study}

In the twentieth century, the world was transformed by changes to social and political structures, and developments in technology and industry. Modernism evolved as artists sought new ways to respond to and represent their changing world. The term modernism refers to artists' self-conscious breaking with the past and their search for new forms of expression (Mackey \& Rachel, 2009). Bradbury, as cited in Childs (2008) puts forward that;

Modernist art is, in most critical usage, reckoned to be the art of what Harold Rosenburg calls 'the tradition of the new.' It is experimental, formally complex, and elliptical, contains elements of de-creation as well as creation, and tends to associate notions of the artist's freedom from realism, materialism, traditional genre and form, with notions of cultural apocalypse and disaster.

Modernist works reveal concerns about art and aesthetics, regardless of whether or not the artist is representing traditional subjects (as in still life). By questioning traditional techniques and methods of representation, modern artists broke through the boundaries established by art academies to pioneer new art-making approaches (Mackey and Rachel 2009). This happening can be likened to the Ghanaian art landscape where her indigenous art was branded fetish and abandoned with the dawning of colonisation and westernisation.

Successive challenges to the traditions of art making in the nineteenth century gave rise to the term avant-garde. From the French for 'vanguard,' the foremost part of an army, it began to be used in relation to art in the 1880s (Mackey and Rachel 2009). Avant-garde referred to artists who were considered to be ahead of their time and challenged established art-making traditions. Artists such as Vincent van Gogh, Paul Gauguin, and Paul Cézanne were among the first to be called avant-garde because of their unique approaches to representing the world. The term avant-garde is sometimes associated with modernism and many modern artists once were referred to as avant-garde.

Now predicated upon what he calls the 'Kantian self-criticism', Clement Greenberg (in his famous 1960 essay 'Modernist Painting') advanced an influential argument which formed the impelling ideology of modernist Art. In this essay, Greenberg prescribes not only individuality and self-sufficiency of the various Arts, but also a positivist as well as a visual approach to practice and experience respectively. Greenberg's theory appears not only hegemonic in character, but it does espouse also a rather reduced and closed solution to the epistemological and the ontological enquiry (Manu, 2009).

Plato's universal forms, having been the source of a tremendous production of art works, the modernist convention degenerates, resulting not only in a formulaic configuration of art works, but also in a universalized metaphorical employment of media and a divorce from the viewer's material context.

Curator-authors Rosalind Krauss and Yve-Alain Bois in a quest to redefine the boundaries of modernism and put the redefinition to use in a shake-up of the art world that will re-deal modernism's cards, catalogues in their book 
'formless' that, 'mainstream modernism of traditional art history, essentially, the modernism of Clement Greenberg,had to justify its existence as the search for its own essence'.

Annku and Lodonu, (2012) postulated that Ghana can boast of very rich indigenous and contemporary artefacts of exceptional intriguing philosophical values and qualities, examples which include; palanquins, linguist staffs, ceremonial swords, akuaba and kuduo. Many of these artefacts, regardless of its media, seem so representational.

Interestingly, deeply rooted in ancient philosophy of objective and subjective universals respectively, this Modernist thought creates the conviction that, there is a single and idealised taste and culminating experience towards which reality evolves in a teleological order

There is, therefore, a supervening need, not only to deconstruct these Modernist myths but also to incite and support incipient ideologies that counteract yet offer more etic stances, in the face of this looming danger.

A taste agreed on by members of one society is their unifying element. In the same society in different time frames, a different taste altogether may be the accepted canon around which their self-definition is carved. Contemporary art embraces a pastiche of criteria and taste; it accentuates on differences of standards not their similarities. What contemporary art proposes is a truce for an abyss of contradictions, lack of essence, the multi-faceted and ever shifting, plurality and the idea of the self as relative (McEvilley, 1999). This, therefore, calls for the sacrilege responsibility of not only questioning but also revising and redefining 'traditional landmarks' in the face of the contemporary ideology.

\subsection{Research Questions}

The study sought to answer the following research questions

- What are the identified iconographies used in the Ghanaian contemporary artist's experience?

- What factors influenced the incorporation of the identified iconographies by Ghanaian contemporary artist?

- How do Ghanaians respond to the identified iconographies used by contemporary artists in Ghana?

- Are there any homologies between the identified iconographies used by Ghanaian contemporary artist and indigenous Ghanaian Traditional Culture?

- What are some of the challenges associated with the use of the identified iconographies by Ghanaian contemporary artists?

\subsection{Purpose of the Study}

The purpose of the study was to catalogue and appraises the major iconographies used by the Ghanaian contemporary artist. It was also to chronicle the motivation behind the preference for these iconographies and guesstimate the challenges associated with the use of these icons all in the quest to gaining insight; explore the depth, richness, and complexity inherent in the works of Ghanaian contemporary artists.

\section{Methodology}

\subsection{Research Design}

The qualitative research approach was adopted and this assisted the researcher to understand underlying phenomena that influenced the choice of iconography used by the contemporary Ghanaian artist. This assisted the researcher to fully understand why certain iconographies were preferred by the contemporary artist to the widely accepted western academic canon iconographies. This unique characteristic of this type of research made it appropriate for the study because, the study required the researcher to use multiple data collection instrument to advance appropriate data that answered the research questions for the study.

Furthermore, the qualitative research approach was preferred because there was the need for the researcher to collect oral data so that during the interpretation and analysis of the data collected, an objective account of the target population would be made. The study was conducted in the qualitative paradigm using grounded theory as the preferred design. According to MacDonald (2001) grounded theory is characterised by its concrete and structured guidelines, a feature that helps researchers in their investigation and is a good fit for the pragmatic approach of the practice of the arts. This forms the major consideration for the choice of this design

\subsection{Research Instruments}

The instruments that were utilized to gather the data were, interviews, participant observation, focus group discussions, audio visuals and documents. The use of multiple instruments helped to improve the validity of the findings and enabled greater inferences from the results.

\subsection{Population, Sample and Technique}

The accessible population of this study comprised practicing Ghanaian contemporary artists registered with the Foundation for Contemporary Art and Students, lecturers and student artists from the Kwame Nkrumah University of Science and Technology Department of painting and sculpture.

A sample size of 41 participants was chosen in a couple of sampling techniques for the study. This sample size was chosen considering the scope of the study, the nature of the topic, the quality of the data and the study design (Morse, 2000). The sample constituted 27 student artists from the Kwame Nkrumah University of Science and Technology, 11 practicing contemporary artists from the FCA- Ghana and 3 lecturers, from Kwame Nkrumah University of Science and Technology and Takoradi Technical University as shown in the Figure 1. 


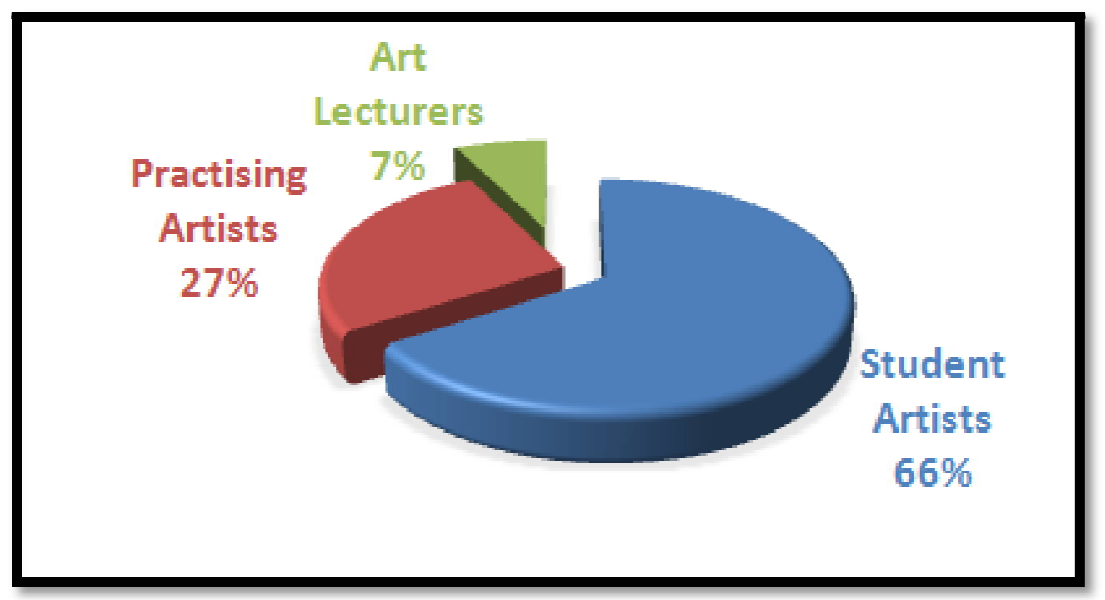

Figure 1: Sample Size

Source: Fieldwork, 2017

The sampling techniques employed for the study was purposive and convenience techniques. The purposive sampling was used to select the practicing artists and the lecturers whereas the convenience technique was used to select the student artists.

\subsection{Data Analysis Procedure}

Data was basically analyzed through visual and concept analysis. Visual analysis addresses an artwork's formal elements-visual attributes such as colour, line, texture, and size while the concept analysis-- looks at the philosophical undertone informing an art work.

Using open coding, the researcher was able to compare the responses of the interactions from one particular interviewee with the rest of the respondents for similarities and differences for conceptual labels to be developed.

Finally, the researcher employed selective coding. With this procedure, all categories were unified around a 'core' category, and categories that needed further explication were filled-in with descriptive detail. This type of coding was utilized at the later phases of this study.

Essentially, the data collected was categorized and analysed by identifying patterns, features and themes. In addition, Thagard and Beam's concept of metaphilosophic analysis was adopted as a multi-dimensional philosophical method of analysis. (Thagard \& Beam, 2004, as cited in Wheeler, 2006, p. 3). Moser (1999, as cited in Wheeler, 2006, p. 4) proposed that met philosophy is concerned about 'the theory of the nature of philosophy, especially its goals, methods and fundamental assumptions'. The intent is to unearth the underlying foundational views that each philosophical perspective is grounded on.

Thematic analysis also allowed for a search for alternative explanations of the data. Subsequently, an application of aesthetic criteria of the per formative turn, and the aesthetic and paraxial philosophical systems was done to the data to bring out the most important and relevant aspects of the various philosophies relating to the art and their implications for art praxis.

\subsection{Discussion of Findings}

The main objective of this research was to find out the main iconography as used by the Ghanaian contemporary artist, what factors informs his/her choice of these iconography, the level of acceptance of their line of practice, the impact they are making on Art in Ghana and the challenges so far faced. In consonance with this, this section presents the results and findings of the study with regards to data obtained from the set of questionnaires, interviews conducted and sample works of these artists. Additionally, data obtained from transcriptions of interviews conducted on the field have also been presented and analyzed in this section to answer the question and objectives of the study. Efforts have also been made to reduce excess work by integrating and analyzing data that are similar and yet seek to answer a particular research question and objectives of the study. In furtherance any definitive information given by respondents during interviews and observations made by the researcher has also been stated.

\subsection{Analysis of Research Questions}

\subsubsection{Research Question 1}

- What Iconographies Are Used In the Ghanaian Contemporary Artist's Experience?

The overarching goal of this question was to find out the various categories and kind of iconographies used by the Ghanaian contemporary artists. 


\begin{tabular}{|c|}
\hline Media \\
\hline Photography/film/technology \\
\hline Fabric \\
\hline Metal \\
\hline Glass \\
\hline Found objects \\
\hline Scrap metals \\
\hline Waste materials \\
\hline Plastics \\
\hline Nature \\
\hline Paint \\
\hline Paper \\
\hline Human body \\
\hline Table 1: Icons Used by Ghanaian Contemporary Artists \\
Source: Field Data, June 2016
\end{tabular}

From the table, it could be seen that the respondents unanimously agreed that Ghanaian contemporary artists utilize a variety of media including photography/film/technology, fabric, metal, glass, found objects, scrap metals, waste materials, plastics, nature, paint, paper and the human body. It could be deduced from the above that the most prevalent iconography used by contemporary Ghanaian artists are fabric, found objects, metals, film, nature and the human body. These findings agree with the views of the practising artists according to the data from the interviews. The following recurrent themes that emerged from the interview transcripts are discussed alongside some selected works of the artists:

\subsubsection{Fabric}

Fabrics have always played a role, albeit often uncelebrated, in visual art. On a basic level, the majority of paintings exist on canvas - cloth. Shonibare, like many other artists drawn to fabrics, plays with our initial assumptions about what the art might mean. His reaction is, in part, a response to expectations of 'authenticity' of his work which he experienced as a student. Shonibare's approach is similar to that of Dorothy Amenukeand Ibrahim Mahamah in the present study. Dorothy's work has long been based on Fabrics and fibres. To her, Fabrics and fibres traditionally speak to that which is intimate, personal and often related to the body and the body's function. Her employment of fibre and fabrics also connote ideas of flexibility, fluidity and multiplicities in engagement with fixity, solidity and stability.

Many artists use fibre/fabric (cloth) to create works of art that to a large extent, act as bridges between social life and the less accessible world of the poetic. In this sense, fibre/fabric becomes the sites/spaces where one may express personal and social concerns artistically, whilst broaching multiple discourses too (Amenuke 2009).

In the following sample statement, Dorothy Amenuke said that:

I initially adapted fabrics in a conventional sculpture approach. That is to say, I produced my sculptures with fabric through modelling, casting or assemblage. I make this possible by employing such techniques as stitching, tying and gluing (Dorothy Amenuke, January 2017).

In view of Dorothy's account. It is okay to merely refer to her works as just sculptures. After all, the conventional methods of the art are employed.Dorothy Amenuke utilizes fabric as the main medium of her communications. Whatever, she wants the public to deduce in her expressions is beneath the fabric as portrayed below:

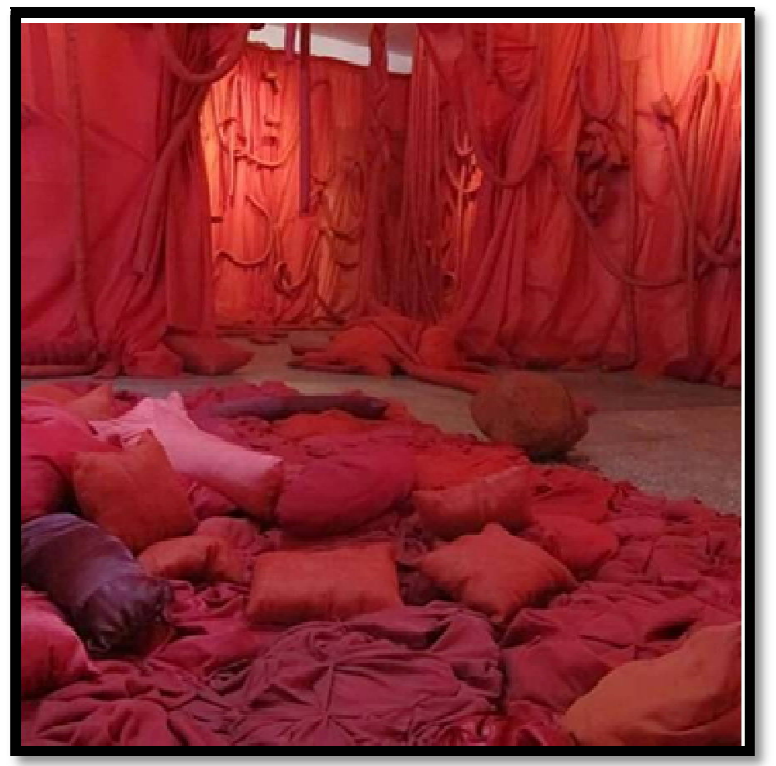

Figure 2: Dorothy Amenuke, Habitation-Inhabitation, 2017 Source: Courtesy the Artist, 2017 
Unmasking the meaning of this work, Dorothy Amenuke's installation embodies the logic of an extraneous system that progressively takes over another, resulting in a new being that is not altogether homogenous. Its presence in the space, whilst merging with this place is what becomes of the new space.

Similar to Dorothy Amenuke, Ibrahim Mahamah also uses fabric in the form of coal sacks to interrogate process, space and time. When asked why the coal sacks? He said:

'For me the coal sack becomes a symbol of the way fabrics are given substance as a commodity in relation to community and context. I re-confront the work in the same kinds of market spaces where I gets the coal sacks. The object most often unseen, seamlessly integrated into daily transactions, becomes the focal point of the scene, made visible through its undoing' (Ibrahim Mahamah 2016).

\subsubsection{Found Objects}

Majority of contemporary African artists' experiment with waste as their preferred artistic medium and find in them (waste), potent metaphors for creative expressionism (Akpang, 2013).

The present study also contended with several contemporary Ghanaian artists who utilize found objects or media in their works.

Serge Attukwei Clottey reorient waste yellow gallons popularly called 'Kufuor Gallons' (plastic jerrycans) into art. Serge Attukwei Clottey uses these waste gallons as his primary material for his sculpture works, installation and sometime his performances. He cuts theses gallon, Gallon by gallon, with the intention of returning used plastic refuse in the form of beautiful masks and mask-like sculptures that take on haunting human expressions. In Ghana, yellow canisters are ubiquitous and have become a seamless part of the country's landscape.

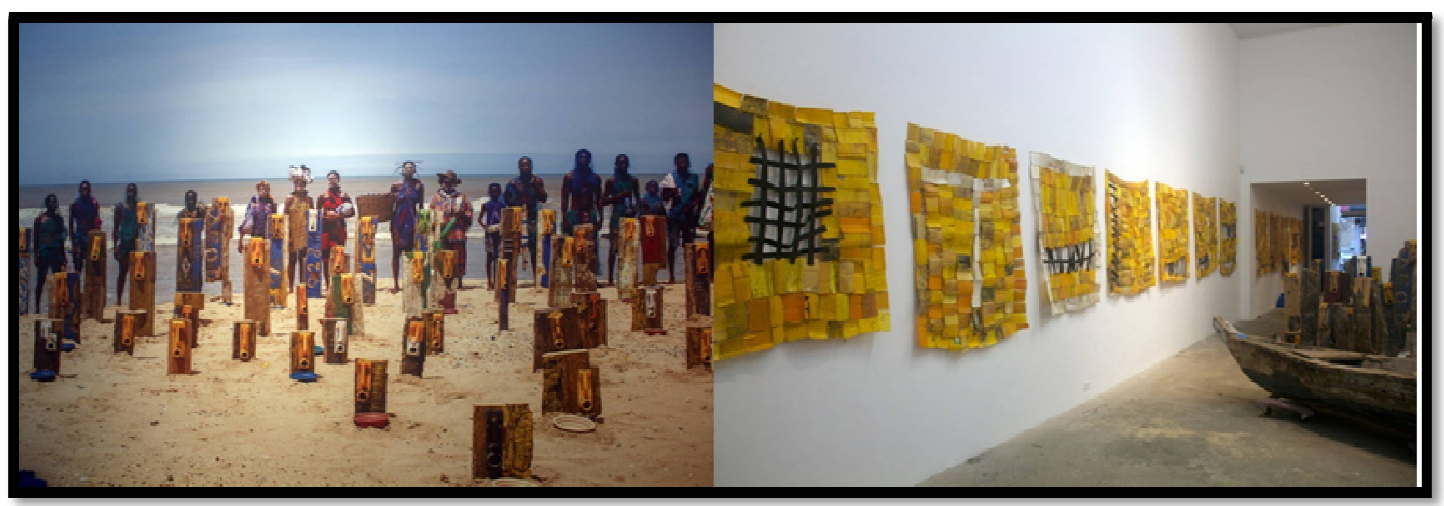

Figure 3: Serge Attukwei Clottey, The Displaced: The Arrival,2015

Source: Courtesy The Artist And Gallery 1957, 2015

The technique of Clottey and many others, lends credence to Kart, (2009) and Akpang, (2013) who indicated waste and found materials occasioned by modernity, become materials for artistic use. The abandoned gallons are obviously a nuisance along the cost of Ghana yet, Clottey is able to employ them as effective visual metaphors for creative explorations and expressionism.

Yaw Owusu reimagines the surplus currency of Ghanaian pecuniary systems, transmogrifying the ubiquitous yet nearly useless pesewa coin into gleaming sculptural bodies and geometric motifs (Riskin, 2016). Yaw Owusu acquired thousands of these paradoxical coins from the Bank of Ghana and some handpicked from people, are fired it into shades of amber, umber and moss. Above all, his one pesewa installations pose questions around economic and political independence in contemporary Ghana.

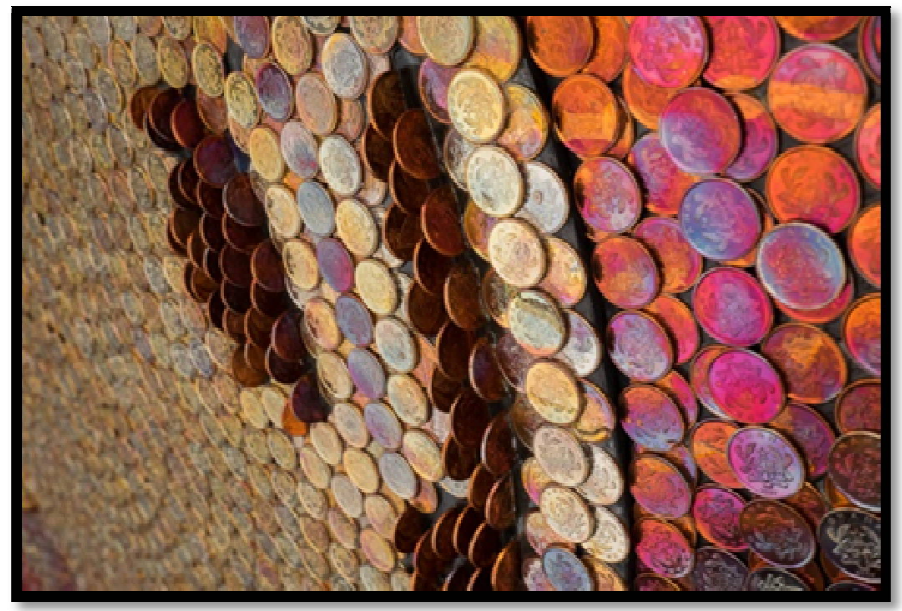

Figure 4: Yaw Owusu, Trial of Change, 2017, Coins on Plywood

Source: Courtesy the Artist, 2017 
Elvis Nsiah, likewise, gathers corrugated roofing, plastic discards, andabandoned containers from slum communities, which he patiently solders into twistedforms that seem to defy their materiality. Along the way, Elvis blends objects from specific states of uncertainty into a world of three-dimensional structure that question past, present and future societies in relation to the existence of slum spaces in urban dwellings of Ghana.Nsiah's recent body ofwork, titled 'Stop Work Produce Permit' (Figure 5), references the noticesof Metropolitan authorities in Ghana preparing to clear out illegal occupants.

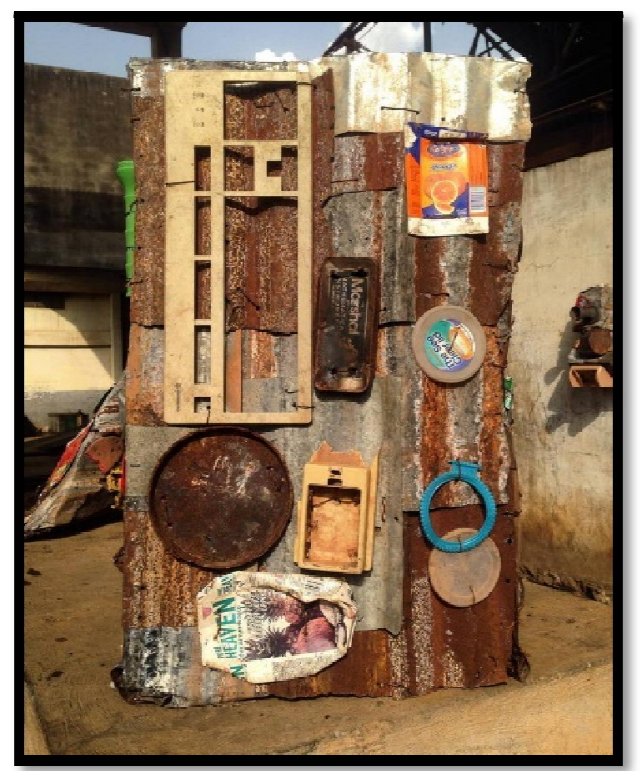

Figure 5: Stop work Produce Permit, Elvis Nsiah, 2016

Source: Courtesy the artist, 2016

Akwale Suma Glory's 'Hall of Fame' (Figure 6) is another thought provoking artwork produced with found objects as the main iconography. She utilized found objects in the shape of rejected kitchen wares, burlap, cloth and iron rods to represent the contributions of individuals to the making of idols. Akwale believes that for a person to become a star or an idol, it takes the contributions of others.

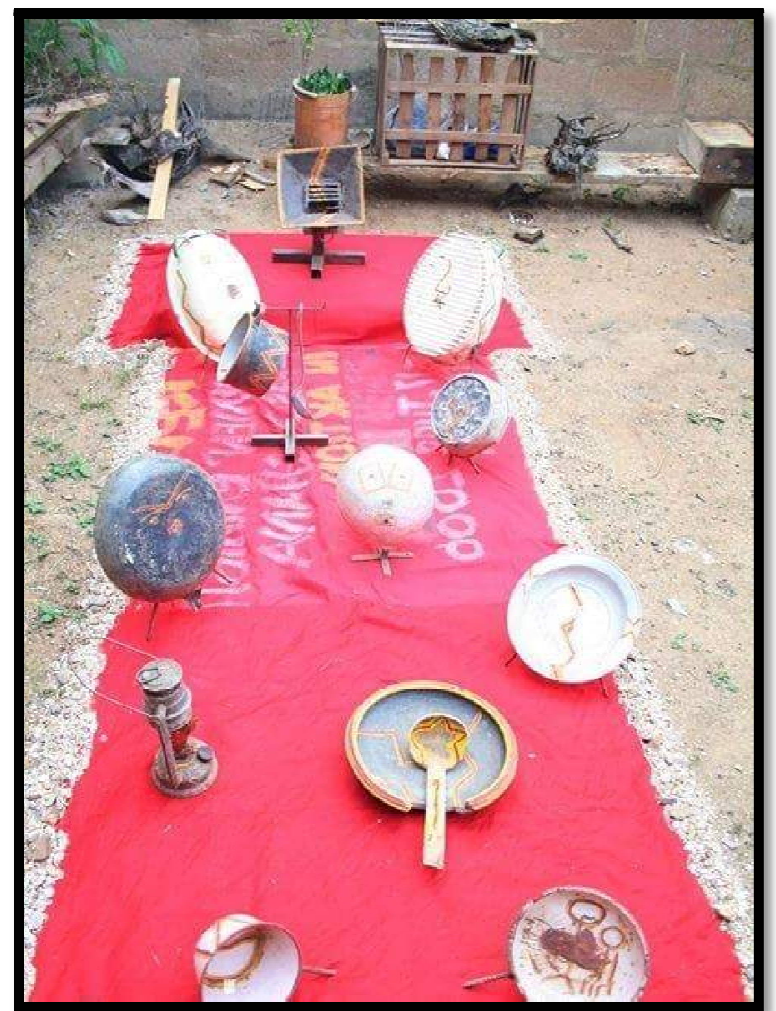

Figure 6: Hall of Fame by Akwele Suma Glory, 2003-2005.

Source: Courtesy Akwely Suma Glory, 2003 
In a similar fashion you find works by EloloBosoka as very intriguing and thought provoking. Like the previous artists who explore the unending possibilities of ideas imbedded in these found objects bosoka manipulates materials like used plastics charcoal sacks and old rusty tomato tins to invoke phantoms laid hidden in the materials' and objects' prosaic use.

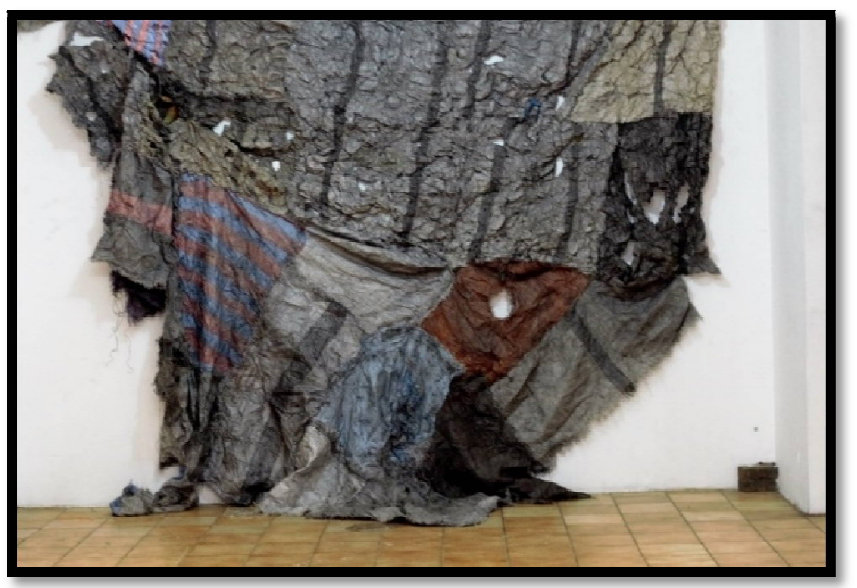

Figure 7: Elolobosoka, Untitled, 2016

Source: Courtesy Researcher, 2016

Following the views of Evans, 2013 and Aniakor, Yaw Owusu and Elvis Nsiah's works has been a reminisce of the work of Marcel Duchamp with his famous display of a ceramic urinal (fountain) (figure11) in 1917. The Fountain made a lot of waves on the art scene because all that Duchamp did was to exhibit this urinal bowl and declared it a work of art. Duchamp is generally believed to be the father of conceptual art, in his insistence that art should be driven by ideas above all.

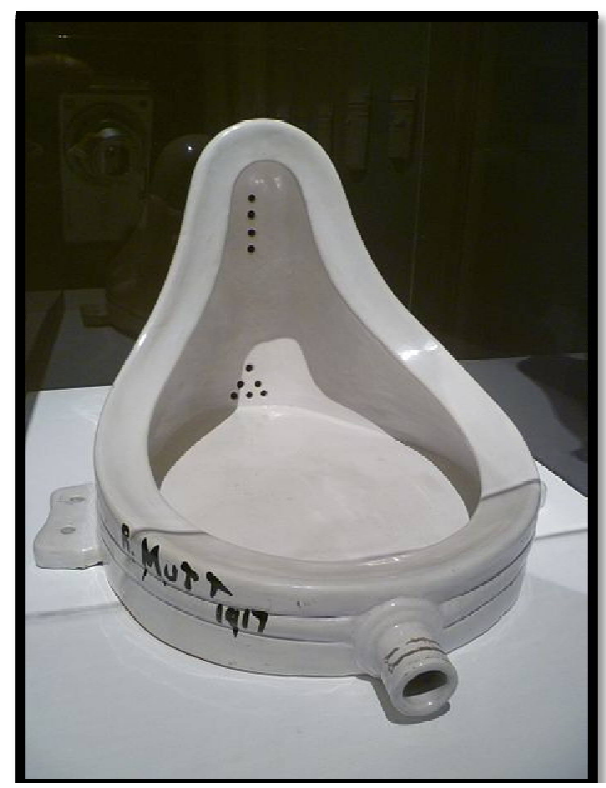

Figure 8: Marcel Duchamp, Fountain, 1917

Source: https://en.wikipedia.org/wiki/Fountain

\subsubsection{Photography/Film/Technology}

Photography and film has been highly influential in the most revolutionary transformations of art in the 20th century, propelling the transition from pictorialism to idea-based-image making.

Interestingly, since independence, photography and film has been a prominent feature of Ghanaian contemporary arts. Felicia Abban is Ghana's earliest known female photographer. Touted as the first female professional photographer, several photographers citeFelicia as the first Ghanaian woman photographer and owner of an Accra studio (Best, 2017).Felicia describes her collection of self-portraits as evidentiary 'calling cards' crafted around her own musings about the early independence period, with clothing as the central expression of her identity (Bowlers, 2016). 


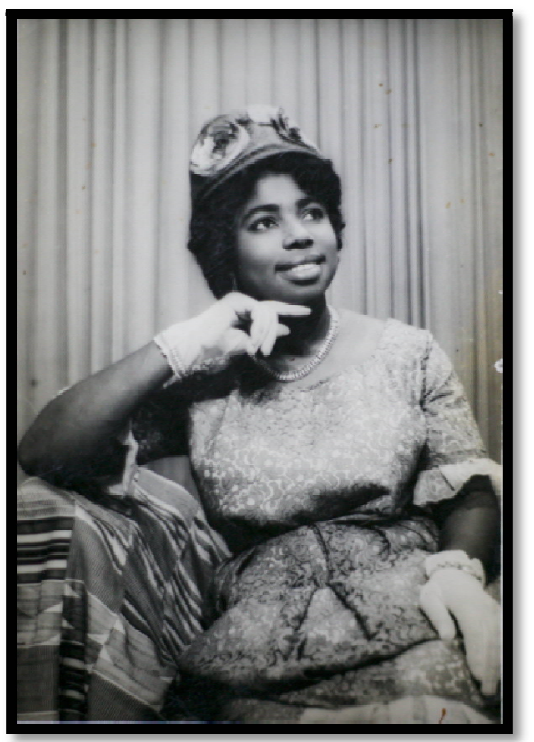

Figure 9: Felicia Abban, Self Portrait, n.d. Source: Courtesy ANO

A striking consistency that runs throughout her collection of portraits is the way she utilizes clothing to visibly articulate a feminine identity that plays with tradition and contemporary in an artful hybridity that is urbane and transAtlantic.

In more recent times, Bright Akwerhis an epitome of a typical sway of the use of photography and technology in the arts. Bright Akwerh's productions have a very distinct creative process. He looks for ways to exaggerate the ideas he has but has to ensure he does not alter the basic truths in the project or concept. He often begins the process with sketches which, potentially, moves into photo shoots of models and then paintings of those creations. He satirical illustrates narratives from popular Ghanaian culture to make commentary on cultural capital and identity politics.

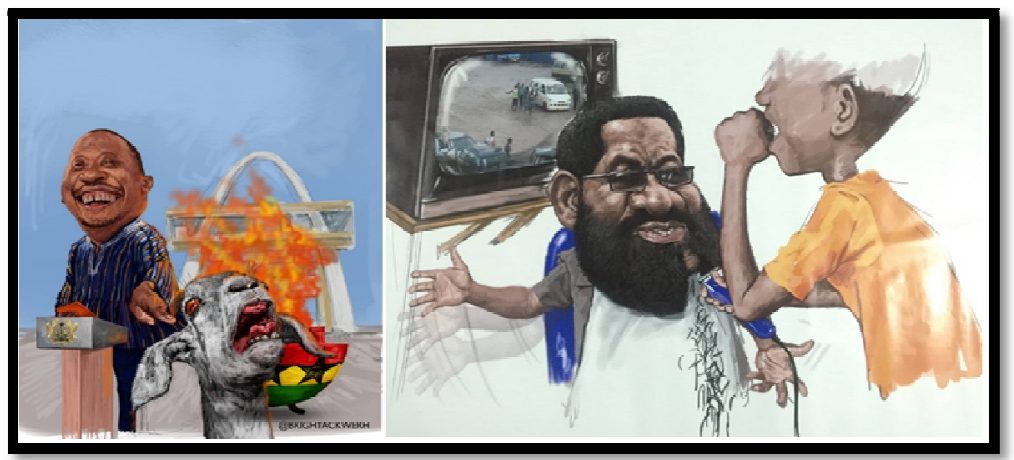

Figure 10: Bright Akwerh, Untitled, 2016

Source: Courtesy Researcher, 2016

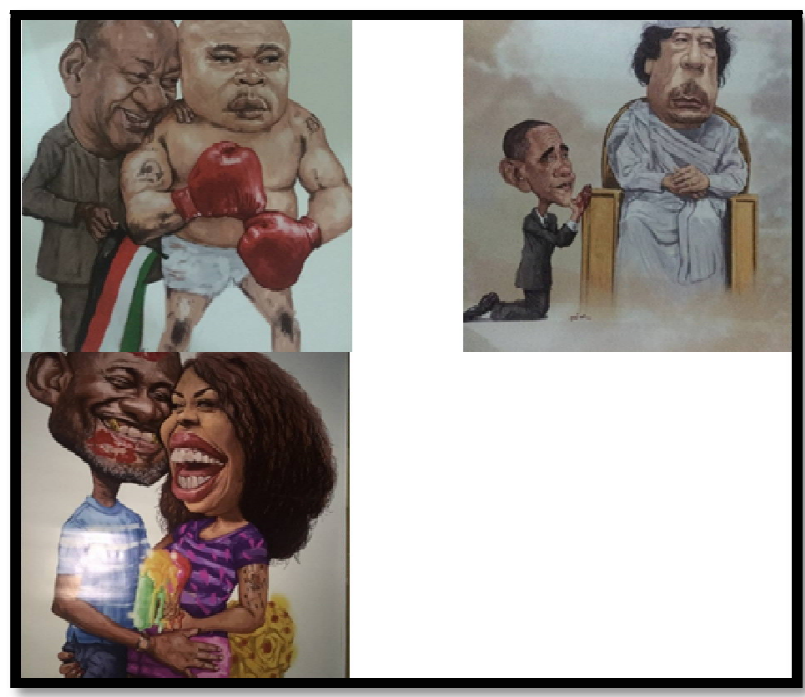

Figure 11: Bright Akwerh, Untitled, 2016

Source: Courtesy Researcher, 2016 


\subsubsection{The Human Body/Performance}

Aside found objects, photography, fabrics, paper which appeared to dominate the iconography used by the Ghanaian contemporary artist, it also came out clear that the human body was also a popular iconography used by the Ghanaian contemporary artist. Central to the process and execution of Performance Art is the live presence of the artist and the real actions of his/her body, to create and present an ephemeral art experience to an audience. Other key components are time, space and the relationship between performer and audience affirming this, is the statement made by Ponty who says;

'Our body is not in space like things; it inhabits or haunts space. It applies itself to space like a hand to an instrument; and when we wish to move about, we do not move the body as we move an object. We transport it without instruments as if by magic, since it is ours and because through it we have direct access to space. For us the body is much more than an instrument or a means; it is our expression in the world, the visible form of our intentions. Even our most secret affective movements, those most deeply tied to the humoral infrastructure, help to shape our perception of things. -MAURICE MERLEAUPONTY.'

Va-Bene Elikem Fiatsi also known as crazinisT artisT, Siege Attukwei Clottey and others like Bernard Akoi Jackson are some the protagonist Ghanaian contemporary artist who use their body as their iconography to push forward their belief in unconditional love for humanity. To the crazinist artist, regardless of one's sense of belonging or identity, it should suffice to investigate and question our quest for socio-cultural supremacy over marginalized people, political injustice, violence, vulnerabilities, human sense of mortality and objectification. he uses his body as a thought provoking tool and material that confront and exploit the stereotypical aesthetics of marginalized citizens within 'so-called' civilized societies while exploring 'rituals of identity', and the tension between 'exhibitionist and voyeurs', the public and privacy through performance photography, nomadic performance (the walking art), experimental videos, films and installations.

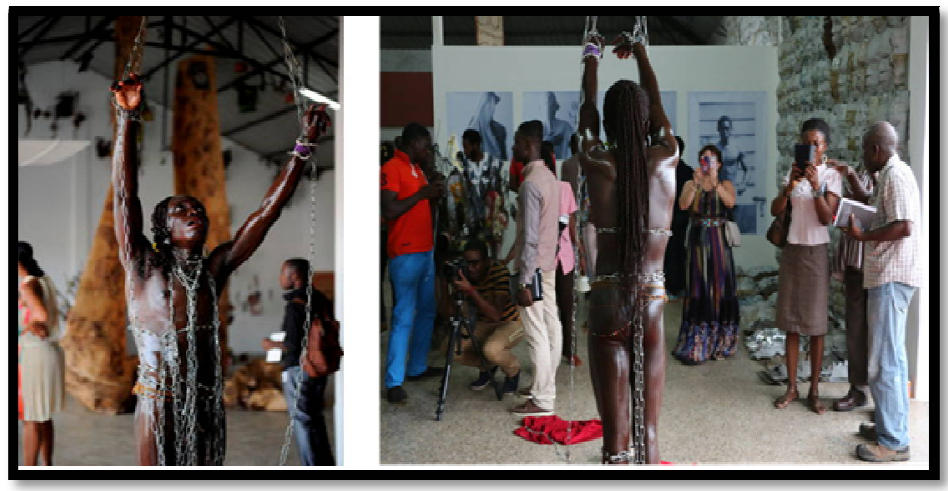

Figure 12: Va-Bene Fiatsi, Stench of Silence, (2015), Performance Installation Source: Field Work, 2015

Similar to crazinisT artisT, Siege Attukwei Clottey who is the founder of Ghana's GoLokal performance collective, also uses his body as part of his work;

'I use myself as an object in my work. I combine myself and my work; my work is the subject and my body is the object. I use my collective as an object as well. We use ourselves to address an issue or a subject. My body is part of my work's mystery. (Siege Attukwei Clottey 2015)'.

His works challenge convention andas is seen in his inaugural performance titled 'Mother's Wardrobe' (figure16). The performance explored narratives of personal, family and collective histories. It consisted of the collective wearing women's clothes. They wore fabrics from different parts of the continent, from old, traditional clothes to modern, contemporary clothes. It consisted of his plastic installation, which basically mimicked his mother's wardrobe, and they had a 'Ghana Must Go bag', which is a rubber bag that women use to transport their clothes from one place to another.

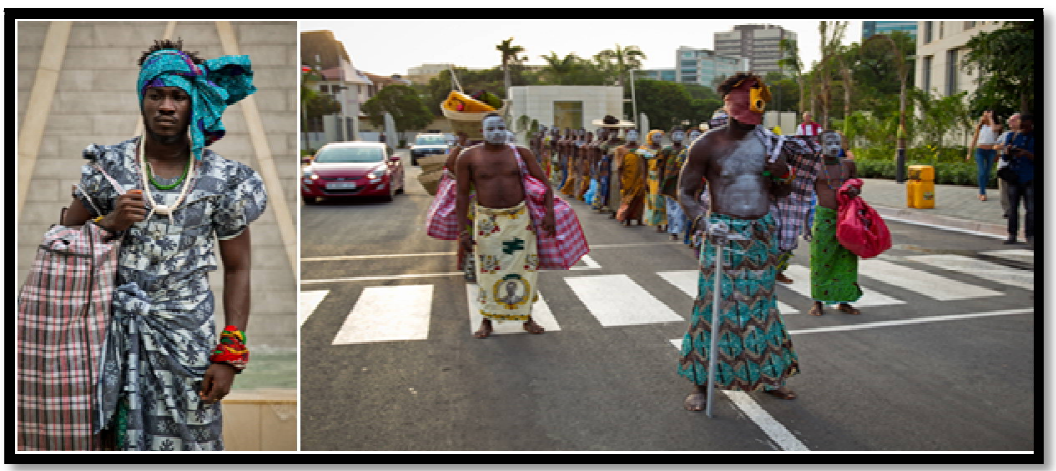

Figure 13: Serge Attukwei Clottey and Golokal, My Mother's Wardrobe, 2016 Source: Nii Odzenma, Courtesy the Artist and Gallery 1957, 2016 
Many people tie in performance art with highly publicized controversies over government support of the arts, censorship, and standards of public decency. Indeed, at its worst, performance art can seem gratuitous, boring or just plain weird. But, at its best, it taps into our most basic shared instincts: our physical and psychological needs for food, shelter, sex, and human interaction; our individual fears and self-consciousness; our worries about life, the hereafter, and the world we dwell in.

\subsubsection{Nature}

The least used iconography, according to the respondents was plastics, nature and paint with the mean score of 2.78 and a standard deviation of .420 that notwithstanding an interaction with some of these artists revealed that some of them have explored extensively with nature as is seen in (Figure 14). These are installation performance works by Togoe and Sampong which they term 'NATURE ART'. In these set of works tagoe and sampong explored beaches in the central and western Regions of Ghana creating ephemeral works with nature. The objective of their work was an inspirational guide to the creative potential of the beaches in Ghana and an opportunity to dialogue with the environment through the use of ordinary things found within nature to create Art. They were further inspired to create these set of works, as a contribution to the current campaigns against the destruction of the environment.

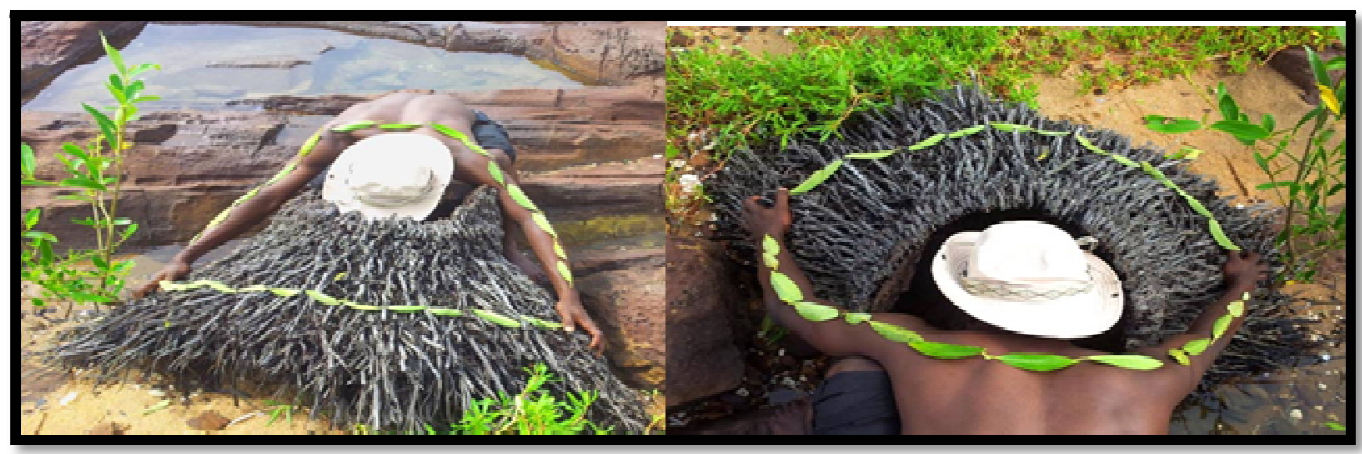

Figure 14: Patrick Tagoe-Turkson, Inside The Black Pot(2012).

Source: Courtesy PAT, 2012

\subsubsection{Research Question 2}

- What Factors Influence the choice of Ghanaian Contemporary art Iconography?

\begin{tabular}{|c|}
\hline Factors \\
\hline Environmental factors \\
\hline Economic factors \\
\hline Political factors \\
\hline Religious factors \\
\hline Educational factors \\
\hline
\end{tabular}

Table 2: Factors That Influence the Choice of Ghanaian Contemporary Iconography Source: Field Data, June 2016

Data in Table 2 depicts the responses of the participants on their views on the factors that influence their choice of iconography. From the table, it could be clearly seen that the most prevalent factor that influences iconography among Ghanaian contemporary artists was environmental.For example, Livingstone Amoako one of the student artists sampled for this work who uses snail shells as his main iconography,reminisces on the times in his village Senegya in the western part of Ghana when snails were abundant and have disappeared with the gradual depletion of the forest. For him they resonate of a global cancer that goes beyond his village; climate change. By stitching these snails to tower-like totem draws our consideration of other life forms' and 'things' that are connected to our very survival' a consideration of an intra-specie co-evolution. (Figure 15).

Again, Eugene Edzorho, another student artist, also takes a swipe on illegal mining popularly called galamsey with his installation titled geological and geometrics re-mappings, He takes a look at the irreplaceable damaged lands and water bodies in these galamsey sites. He does this by collecting rocks from Galamsey mining sites and accumulate them in entropic installation that exist as a collective body for brief moment (Figure 16).

This factor is closely followed by education which was agreed upon by the respondents. Similarly, the respondents agreed to religious factors as the next source of influence in Ghanaian contemporary iconography. The environment forms a very important source of inspiration for several artists. From the senior high school level where students are taught 'idea development' through the tertiary level where students are taught 'basic design', the environment has become an important feature in the arts. It therefore follows that many of the artists interviewed for this study do not work in isolation of their environment. 


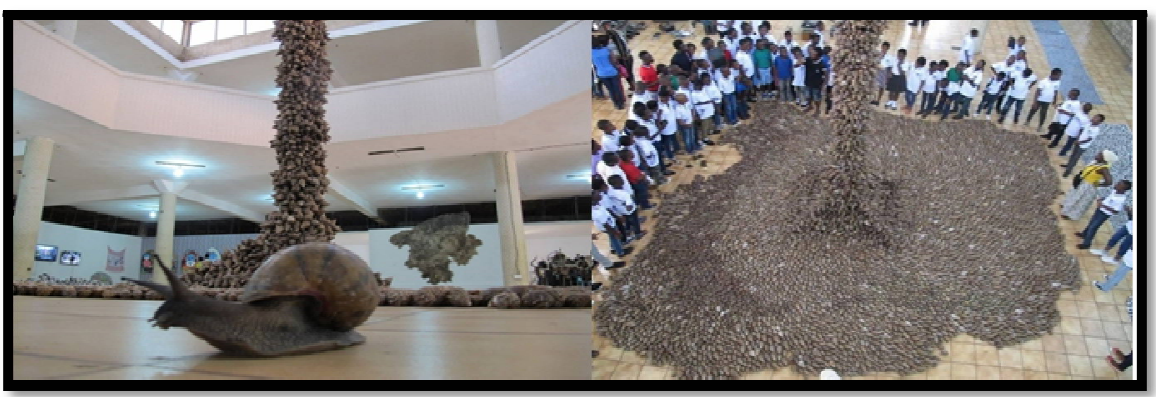

Figure 15: Livingston Amoako, Snail Installation, 2016

Source: Field Work Data,2016

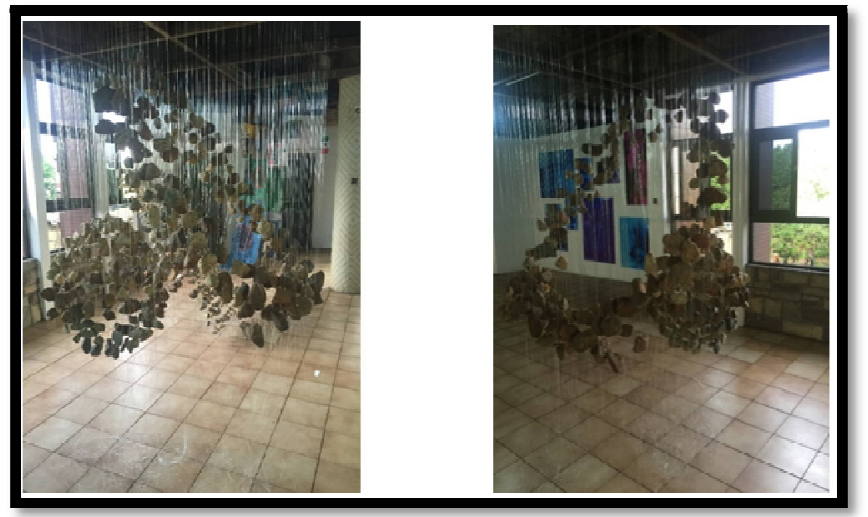

Figure 16: Eugene Edzorho 2016 (Rock Installation) Source: Field Work Data, 2016

Following the factors above, the respondents claimed that political factors. This is vividly articulated by installations and a number of performances by Va-Bene Elikem Fiatsi also known as crazinist artist a Ghanaian-Togolese multidisciplinary artist living and working in Ghana. Some of his political performances include, Triptych; which was a collaborative performance between Natascia Silverio (Italy), Dean Hutton (Golden Dean, South Africa) and crazinist artist (Va-Bene Fiatsi, Ghana) at the 5th annual Chale Wote Art Festival, 2015. In the performance, the artists presented their bodies to interrogate the diverse provocations, taboos and politics that converge on body under the prejudices of colour, culture, religion, race, gender and sexuality (Figure 17).

Again in a performance installation titled 'pieta-African resurrect' in front of the Bible House, opposite the James Fort Prison by the duo, they question the disabled mind and the dependent throne of governance in many African nations.

Furthermore, in 'The Return of the Slaves', crazinist artist employs about 60 participants, both local and international in a durational performance, 12 hours in Elmina Castle slave dungeon overnight without food and water. This active engagement investigates the ostensible 'Dungeons without Wall' as a social process in our contemporary time. Interestingly, the least among the factors that influenced Ghanaian iconography was economic factors

Following the analysis above, it was ascertained that indeed, Ghanaian contemporary iconography is influenced to a large extent by the aforementioned factors. In furtherance of the above, it is clear that the works of contemporary artists with regards to Ghanaian iconography is by and large influenced by myriad factors including environmental, educational, religious, political as well as economic. It could therefore be deduced from the discussions so far that Ghanaian contemporary art Iconography is indeed influenced by so many factors such as discussed above.

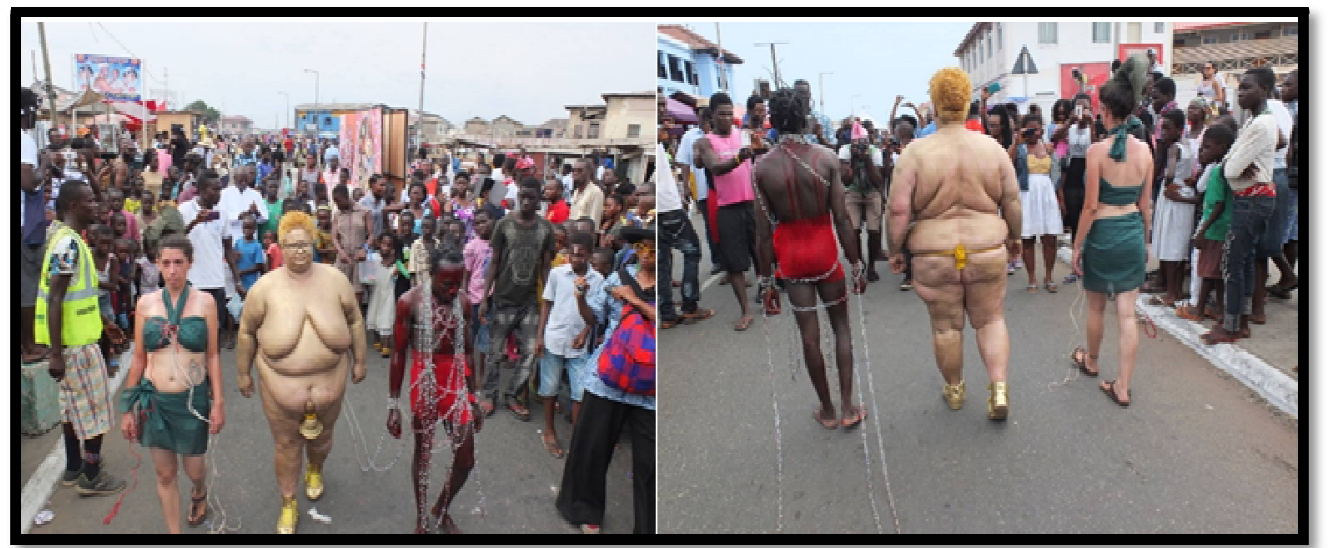

Figure 17:Va-Bene Fiatsi, Natascia Silverio, Dean Hutton, 'Triptych', 2016 (Street Performance) Source: Courtesy the Artist, 2016 


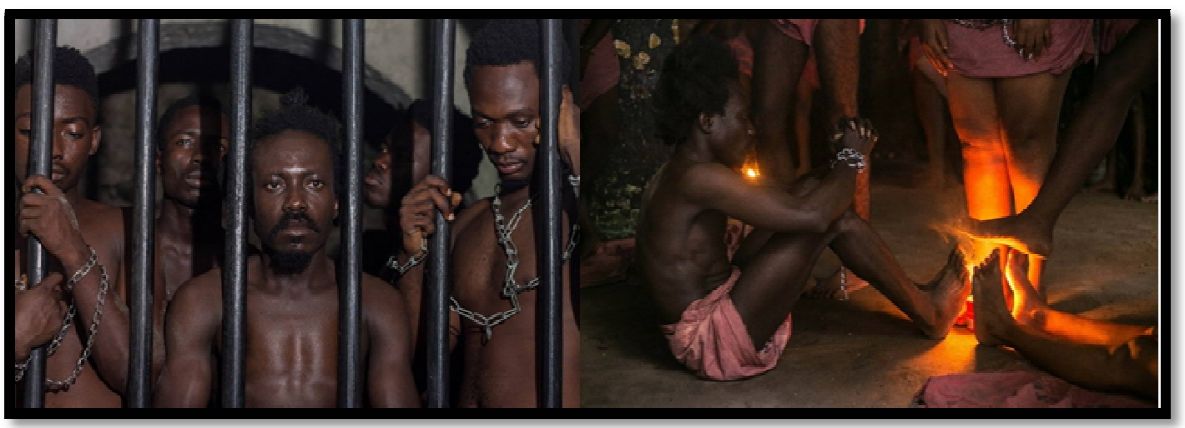

Figure 18: Va-Bene Fiatsi, the Return of the Slaves, 2015 Source: Courtesy the Artist, 2015

\subsubsection{Research Question 3}

- What is the level of acceptance of these iconographies used by Ghanaian contemporary artist?

Research question 3 sought to find out the level of acceptance of these iconographies used by Ghanaian contemporary artist.

The primary aim of this question was to find out the level of receptibility of the activities of these group of artists. There was a mixed reaction during the interviews when this question was posed to the respondents. Most of the artist interviewed made the point that, they were not particularly interested in the receptibility of their audience with regards to their works but rather, they were more interested in how well their choice of iconography (materials) or medium best helped them to put forward their intent. One of them opined;

'My work is not well known in Ghana, but on feedback the comments I have received so far show that, people are curious and want to know more about my technique.Through my exhibitions, people have now ventured into this style of printing'.

'Another artist recounted that, at the beginning, there were a lot of negative comments about his line of Art. It took a while for people to understand the concept, because gender issues are very challenging topic in Ghana. He says; Recently, when I posted an image of an article about my work at the Cape Town Art Fair, someone commented that I was supporting gays Its very interesting how people look at images and make assumption so I want to push the idea further to make people understand the context of it'.

To be accepted depends on whether people understands or buy into your mode of expression which comprises of your philosophy, technique and the materials used.

\subsubsection{Research Question 4}

- What connection do these iconographies used by Ghanaian contemporary artists have with traditional Ghanaian culture?

Research question 4 sought to find out if there was any link between the iconography used by Ghanaian contemporary artists and Ghanaian traditional culture. In the process, it would be quite clear to ascertain whether or not the iconographies utilized by the Ghanaiancontemporary artist have a bearing on Ghanaian culture. Data gathered from the transcribed interviews showed the views of the respondents on the correlation between the kind of iconography being used by the Ghanaian contemporary and Ghanaian traditional culture. There was a unanimous agreement to this assertion by the respondents that, Ghanaiancontemporary iconography had a direct homology to traditional Ghanaian culture. Respondents also agreed that Ghanaian contemporary artist use local scenes to portray traditional Ghanaian culture.

In consonance, the statement that, Ghanaian contemporary artist uses Ghanaian languages to portray traditional Ghanaian culture was very common in the comments of majority of the respondents. A further probe also revealed that, Ghanaian contemporary artist use Ghanaian proverbs to portray traditional Ghanaian culture. Finally, there was a unanimous agreement that Ghanaian iconography has an impact on culture and tradition from the viewpoint of theGhanaiancontemporary artist.

\subsubsection{Research Question 5}

- What are some of the challenges associated with the iconography used by Ghanaian contemporary artists?

Research question 5 sought to find out if any, some of the challenges associated with the iconographies as used by Ghanaian contemporary artists. From the data gathered it was clear that the Ghanaian contemporary Artists in their quest to utilize iconography in their various expressions, face quite a number of challenges. Through the interview transcript, misinterpretation was a recurrent theme worthy of discussion.

Whilst there is no doubt about the meanings of the iconography of the Ghanaian contemporary artist from the artist's own perspective, the iconography are visual literacies that hold semantically deep meanings and perspectives. There is little acknowledgement as to how the iconography utilised by the contemporary Ghanaian artist achieve a psychological response and transference from the external image to the internal body by its audience. There is a general feel of apprehension, uncertainty and misinterpretation. This perhaps explains why sometimes iconography interpretations are linked from the transition from an image to an icon, which makes it semantically deep and gives a semantic perspective. One of 
How people react to what you do is very important. I try to test people's pulses, the reaction to the simple things. Sometimes you realise that the simple things that we are familiar with when you put it into a different contexts stimulate us in different ways ....For instance, there is one site specific performance which I did with the white cloth which did magic even though it almost nearly led to me being lynched at Lake Bosomtwi (Figure 19).. I went to the bank of lake Bosomtwi with the white cloth, chatting with people, everything seemed ok till I covered my body with the cloth and squated facing the lake, hell broke loose because they didn't understand my performance and thought I was desecrating their gods so we had to go solve the problem at the Chief's palace (Tagoe Turkson 2015)

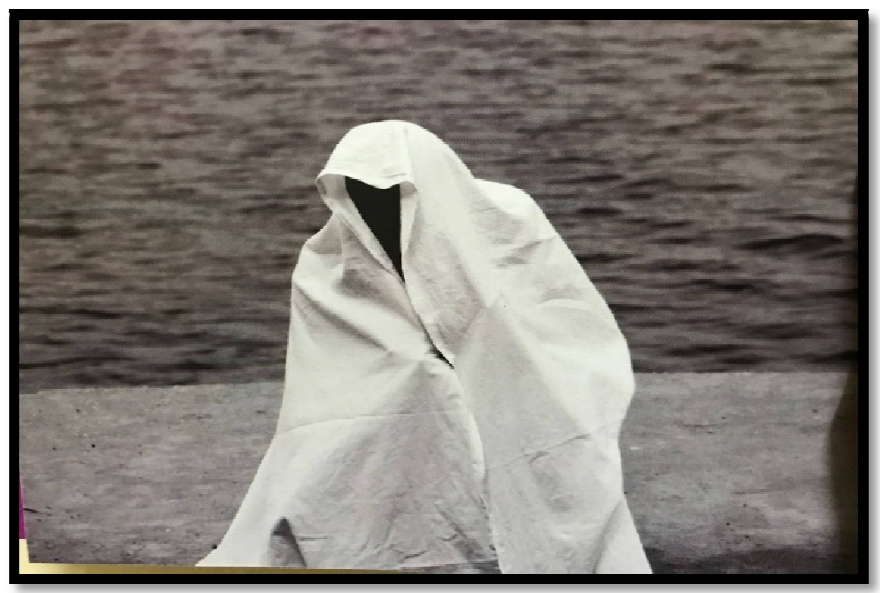

Figure 19: Patrick Tagoe-Turkson

(Performance with the White Cloth at Lake Bosomtwi) 2015

The artists unanimously agreed that there was a general lack of technical skills which cowers their efforts to utilise iconography. Interestingly, the artist also agreed that there is lack of support, lack of raw materials and financial constraints that hinder the Ghanaian contemporary artists' choice for iconography in their endeavours. Lastly, the artist declared that indeed there was a lack of role model artist in the society to help push their agenda. What they meant by this was that as at now they don't have a well-known or better still an icon in this field of art practice who command some kind of authority to help push their agenda.

Furthermore, during my interaction with these artists, it also came out clear that, there hadn't really been a very strong contemporary space before Gallery 1957. Most of the time, these artists just find their own space to show their work. There isn't a contemporary art museum or a contemporary arts centre, so most artists leave the country because there's no sustainability for their kind of art in our part of the world. Some of the artist also said things were not easy from the beginning, this was because people were unsure about it especially where others had to be roped in to assist either with an installation or a performance. One intimated that;

The guys who are in my performances are not creative people actually; they are from different vocations. There are a lot of creative people in the community where I was born, but they don't have the platform to explore that. As an artist, I have that platform so I find a way to bring them together to address issues in our community. Since then, it has been really challenging. The subjects I work on are very political. I take in very religious subjects as well. I explore gender identity. Over time, people have become a bit savvier.

Another artist intimated that they were;

Looking ahead to this new government [The New Patriotic Party won the national election in Ghana in December last year, ousting the sitting party], which has assured to build contemporary museums. But, as artists, we are very political with our work and we criticize the political system because there hasn't been any support for the arts. We feel marginalized because we get most of our funding from abroad or use our own funds to execute our task.

\section{Conclusion}

In the foregoing pages an attempt has been made to conclude the study by making inferences to the main findings of the study. It was deduced from the findings in the study that the Ghanaian contemporary artist utilises a variety of iconography which includes photography, film, technology, fabric, metal, glass, found objects, scrap metals, waste materials, plastics, nature, paint, paper and the human body in their art praxis.

It was also deduced from the findings that, the choice of iconography as employed by the Ghanaian contemporary artist was influenced by a myriad of factors most prevalent amongst these factors was environmental. The environment formed a very important source of inspiration for most of these contemporary artists. The environment has always been an important feature in the arts. Inferences from the findings of the study again indicated that there was a mixed reaction with regards to the level of acceptance of the work of these contemporary artists by the Ghanaian audience. Data analysed showed a contradiction in this regard. Views of respondents was almost split in two with half agreeing to the fact that contemporary art was accepted and the other half disagreeing that contemporary art was not accepted. It was clear from the findings that majority of these contemporary Ghanaian artist draw lots of inspiration from our rich traditional and 
cultural beliefs. Most of what these groups of artists were doing had lots of traditional cultural underpinnings. For instance, works produced by some of these artists examine the role of indigenous textiles, traditional culture, migration, nature in the materialisation of concepts beyond the individual's corporeal reality, between this notion of the unseen and the immanent.

The artists unanimously agreed that there was a general lack of technical skills which cowers their efforts to utilize iconography. Interestingly, the artist also agreed that there is lack of support, lack of raw materials and financial constraints that hinder the Ghanaian contemporary artists' choice for iconography in their endeavours. Lastly, the artist declared that indeed there was a lack of role model artist in the society to help push their agenda.

Furthermore, it also came out clear that, there hadn't really been a very strong contemporary space before Gallery 1957. Most of the time, these artists just find their own space to show their work.

The presentation of contemporary art was not bound to museums and galleries as was seen by most of the works reviewed in the study, but rather the works were moved to other public spaces, such as shopping malls, the streets, lorry parks the beaches, riverbanks and many more, which provided it with an audience that was not in touch with art and would never be seen in an art institution.

Lastly it became clear that aside these group of artists seeking to bring a new wave of refreshing vibrancy to the art scene they also sort to interrogate history - firmly rooting their practice in social/self-reflection - to enable their audience come to terms with their own cultural identity. Identity formation therefore becomes a process understood through art practice.

\section{References}

i. Aesthetics and Phenomenology, 1:1, 63-90, DOI: 10.2752/20539339XX14005942183973

ii. Akoi, J. B. (2013) nkpae (libations) Retrieved from http://prairieschooner.unl.edu/fusion/libations/nkpaelibations

iii. Akoi, J. B. (2014). Bernard Akoi-Jackson performing his goodbyes to Amsterdam. Retrieved from https://contextwithoutwalls.wordpress.com/2014/11/05/linking-with-bernard-akoi-jackson/

iv. Akoi-Jackson, B (2006). Okadii (Marking): Metaphoric Dialogues across Borders. [Unpublished MFA thesis]. Kumasi: UST.

v. Akpang, C. E. (2013) 'Found Object, Recycled Art, Readymade or Junk Art? Ambiguity in Modern African Art', Arts and Design Studies, 12 (1), pp. 41-48.

vi. Amenuke, D. (2016). Exhibitions. Retrieved from http://dorothyamenuke.com/exhibitions/2016

vii. Aniakor, C. (2013) 'Views on the Concept of Found Object in African Art'. Interviewed by Clement Akpang, Audio, 16 September

viii. Annku, M. F. \&Adu-Agyem, J. (2012), 'The Impact of Globalization on The Arts in Contemporary Ghana', Ghana Mining Journal,

ix. Annku \& Lodonu, (2012). Consumption of Visual Art Forms in Contemporary Ghana International Journal of Humanities and Social Science. Vol. 2 No. 17; September 2012.

x. Barth J. (1979) The Literature of Replenishment, later republished in The Friday Book'(1984)'.

xi. Barthes, R., 1967a, Elements of Semiology, Lavers, A. and Smith, C. (trans.) London, Cape.

xii. Barthes, R. (1977). The death of the author. In R. Barthes (S. Heath Trans.), Image, music, text (pp. 142-148). New York, NY: Hill and Wang.

xiii. Best, S., \& Kellner, D. (1991). Post-modern theory: Critical interrogations. London: Macmillan Education Ltd.

xiv. Best, T. (2017). Ghana a changing portrait of Accra. The New York Times, Retrieved on (10th October, 2017) from https://lens.blogs.nytimes.com/2017/03/07/in-ghana-a-changing-portrait-of-accra/

xv. Bois Yve-Alain Krauss (1997) Formless A Users Guide. Retrieved from https://www.google.com.gh/search?ei=4vy4Wv_mEoKzUdOFi6AL\&q=rosalind+Krauss+YveAlain+Bois+1997+redefining+the+boundaries+of+art+pdf\&oq=rosalind+Krauss+Yve-Alain+

xvi. Callinicos, A. (1989). Against post-modernism: A Marxist critique. Cambridge, UK: Polity Press.

xvii. Charmaz, K. (1983). The grounded theory method: An explication and interpretation. In R. Emerson (Ed.), Contemporary field research (pp. 109-126). Boston, MA: Little, Brown and Company.

xviii. Childs, P. (2008). Modernism. USA Routledge 2Pack Square, Milton pack Abingdon, Oxon 0x144RN

xix. Cohen, D., \& Crabtree, B. (2006). Qualitative research guidelines project. http://www.qualres.org/HomeEval3664.html

xx. Cohen, L., Manion, L., \& Morison, K. (2007). Research Methods in Education. (6th ed.). London: Routledge.

xxi. Domfeh, K. (2013). Jute sacks go on artistic exhibition in Kumasi. Retrieved from https://www.modernghana.com/news/448348/1/jute-sacks-go-on-artistic-exhibition-in-kumasi.html

xxii. Downey, A. (2008). 'Setting the Stage: Anthony Downey in Conversation with Yinka Shonibare.' Yinka Shonibare $M B E$. Munich: Prestel, 38-45. Retrieved from http://www.anthonydowney.com/2008/11/30/yinka-shonibarembe/

xxiii. Downey, A. (2008). Setting the stage: Yinka Shonibare in conversation with Anthony Downey in: Yinka

xxiv. Enwonwu, O. \& Akpojiyovbi, A. (2016). The Contextual Textiles of Zohra Opoku. Retrieved from https://www.omenkaonline.com/contextual-textiles-zohra-opoku/

xxv. Enwonwu, 0. (2017). crazinisT artisT: Rituals of Becoming. Retrieved from https://www.omenkaonline.com/crazinist-artist-rituals-of-becoming/ 
xxvi. Fraenkel, J. R. \& Wallen, N. E. (2003). How to design and evaluate research in education. (5th ed.). Boston: McGraw-Hill Inc.

xxvii. Freud, S. (1920). A general introduction to psychoanalysis. Retrieved from (March 26, 2015) from https://eduardolbm.files.wordpress.com/2014/10/a-general-introduction-to-psychoanalysis-sigmundfreud.pdf

xxviii. Geyh, P. (2003). Assembling post-modernism: Experience, meaning, and the space in Between. College Literature, 30(2), 1-29.

xxix. Glaser, B. (1998). Doing grounded theory: Issues and discussions. Mill Valley: Sociology Press.

xxx. Golden, T. (1993). What's white? In 1993 Biennial Exhibition Catalog. New York: Whitney Museum of Art.

xxxi. Greenberg C, (1960), Modernist painting, Retrieved on (12 may 2016) from http://www.yorku.ca/yamlau/readings/greenberg_modernistPainting.pdf

xxxii. Hassan, S. M. (2001). Self and other in contemporary African Art. Retrieved on (October 10, 2007) from https://monoskop.org/images/1/11/Hassan_Salah_M_2001_Insertions_Self_and_Other_in_Contemporary_Afric an_Art.pdf

xxxiii. Henning, E. B. (1977). Fibreworks. Cleveland, OH: Cleveland Museum of American Art. Jost Shonibare MBE (London: Prestel, 2008).

xxxiv. Hicks, (2004). Explaining postmodernism, skepticism and socialism from Rousseau to Foucault. USA. Scholargy Publishing Tempe New berlin/Milwaukee.

xxxv. Hutchens, J. \& Suggs, M. edsC (1997). Art Education: Content and Practice in a Postmodern Era, Washington, DC: NAEA,

xxxvi. Hutcheon, L. (1988). A poetics of post-modernism: History, theory, fiction. New York: Routledge.

xxxvii. James Hutchens \& Marianne Suggs, edsC. (1997.) Art Education: Content and Practice in a Postmodern Era, Washington, DC: NAEA,

xxxviii. Kant, I. (1949). Critique of practical reason and other writings in moral philosophy. Chicago: University of Chicago Press.

xxxix. Kant, I. (2007). Critique of judgment (J. D. Meredith, Trans.). Oxford: Oxford University Press.

xl. Kart, S. (2009). The phenomenon of récupération at the Dak'Art Biennale. African Arts, 42(3), 8-9

xli. Krauss, B. Y. (1997). Formless A Users Guide. Retrieved from https://www.google.com.gh/search?ei=4vy4Wv_mEoKzUdOFi6AL\&q=rosalind+Krauss+Yve-

Alain+Bois+1997+redefining+the+boundaries+of+art+pdf\&oq=rosalind+Krauss+Yve-Alain

xlii. Krauss, R. E. (1985). The originality of the Avant-grade and other modernist myths. Cambridge, Mass: MIT Press.

xliii. Levine, S. (n.d.). Sherrie Levine. Journal of Contemporary Art. Retrieved March 4, 2008, from http://www.jcaonline.com/sherrielevine.html

xliv. Mackey \&Rachel, (2009)what makes modern art modern? Museum Associates/Los Angeles County Museum of Art. All rights reserved

xlv. Manu-Kobia M. (2009). Hybrid Dimensions in Sculpture: A Binary Study. [Unpublished MFA thesis]. Kumasi: UST.

xlvi. McEvilley, T. (1999). Art and Otherness: Crises in Cultural Identity. New York: McPherson and Company.

xlvii. McEvilley, T. (1999). Art and Otherness: Crises in Cultural Identity. Kingston, New York Document Ext/ McPherson \&Company.

xlviii. Mensah, (2009) Dialectical Dialogues in Postmodern Sculpture. Published thesis. Retrieved from http://ir.knust.edu.gh/bitstream/123456789/464/1/DIALECTICAL\%20DIALOGUES\%20IN\%20POST\%20MOD ERN\%20SCULPTURE

xlix. Moore S. (2000). A need to try everything: patient participation in phase 1. J Adv Murs 33(6):738747.

l. Morse J. (2009) Developing Grounded Theory: The Second Generation. Walnut Creek, CA. Left Coast Press,

li. Morse, J. M. (2000). Determining sample size. Qualitative Health Research, 10(1), 3-5. doi: $10.1177 / 104973200129118183$

lii. Ohene-Ayeh, K. (2014). Ibrahim Mahama: Preserving Material History through Exchange. Retrieved from https://iubeezy.wordpress.com/texts/2464-2/ Arts: An introductory reader. London: Routledge.

liii. Woets R. (2013). Doing Sankofa with multi-media artist Bernard Akoi-Jackson: What Zwarte Piet can learn from Ghanaian symbolism. Retrieved from http://standplaatswereld.nl/2014/11/29/doing-sankofa-with-multimedia-artist-bernard-akoi-jackson-what-zwarte-piet-can-learn-from-ghanaian-symbolism/

liv. Yin, R., K (2003). Case study researcher: Design and methods. (3rd ed.) Thousand Sage Publications. 